and then a flock of geese came in and they killed eight of them and then another flock came in of three or four and they killed them all, and then finally there was another flock, and they were both under the same robe, and there was about a dozen in that bunch and Frank said to John, "I'll tell you when to shoot," and so he left it up to my brother to tell him when to shoot, and then the geese swung around and he said, "Shoot, John," and he turned the robe over so it fell over John, and he killed three of them. John finally cleared himself of the robe and then he shot three geese himself.

\title{
WILLING TO DIE AS HE HAD LIVED
}

"One of the most outstanding events in my life," writes Dr. John H. East of Denver, a member of the Colorado State Historical Society, "was in attending Col. W. F. Cody-Buffalo Bill-the bravest man I ever saw die. When asked if he would like to see a minister, his reply was, 'I am willing to die as I have lived-on the square.' He was a good friend of mine. I asked him when taking his chart history how old he was. His reply was, 'seventytwo, and two hundred years in experience.' I held his hand in death and, as he passed away, he held my hand, raised his head and, looking into the future, lay down and passed over the range."-The Colorado Magazine.

\section{POLITICAL EQUALITY IN IOWA}

At a meeting of the Iowa State Teachers association in Marshalltown in 1869, Prof. T. S. Parvin "called attention to the fact that in 1857 the Association resolved in favor of woman suffrage." Also at a meeting of the Iowa Press association in Keokuk, the same year, J. L. McCreery, a famous Iowa poet, read a poem on the subject, the closing paragraph being:

So the conflict goes on, betwixt might and the right, But even today the assurance grows bright. That in ages to come, as in centuries past, Injustice shall fail, and Truth triumph at last. 
Copyright of Annals of Iowa is the property of State of Iowa, by \& through the State Historical Society of Iowa and its content may not be copied or emailed to multiple sites or posted to a listserv without the copyright holder's express written permission. However, users may print, download, or email articles for individual use. 